\title{
СЕЛЬСКОЕ ХОЗЯЙСТВО ВОСТОЧНОЙ СИБИРИ В КОНЦЕ 1980-х - 1990-е гг.: ДИНАМИКА, ОТРАСЛЕВАЯ И ОРГАНИЗАЦИОННО- ПРОИЗВОДСТВЕННАЯ СТРУКТУРА
}

Аннотация. Осуществляется реконструкция динамики сельского хозяйства Восточной в Сибири в 1990-е гг., описание происходивших в его рамках структурных изменений и выявление ключевых факторов развития отрасли. Установлено, что следствием радикальной аграрной и экономической реформы стал самый продолжительный кризис сельского хозяйства региона. Наиболее глубоким был кризис в животноводстве. Это проявилось в резком падении поголовья продуктивного скота. Больше всего пострадало овцеводство. Уменьшение поголовья скота всех видов происходило преимущественно за счет крупхозов. В растениеводстве произошло сокращение посевных площадей. Наиболее значительно уменьшились посевы кормовых культур, что было связано с сокращением поголовья скота в крупхозах. В то же время снижение посевов пшеницы в целом по региону было относительно небольшим. В аграрном секторе экономики Восточной Сибири произошли радикальные структурные сдвиги. Вопреки замыслам реформаторов, в отрасли стали доминировать не фермерские хозяйства и акционированные предприятия, а личные приусадебные хозяйства сельских жителей. В результате место неэффективного государственного сектора занял неэффективный частный. В наибольшей степени кризис затронул Туву, Читинскую область, Бурятию и Хакасию. Насаждаемые в них в советский период системы ведения сельского хозяйства не корреспондировались с местными природно-кли- 
матическими условиями и менталитетом аборигенного населения.

Ключевые слова. Аграрная реформа 1990-х гг., сельское хозяйство, растениеводство, животноводство, Восточная Сибирь.

Финансирование. Работа выполнена по проекту № 0326-2016-0001 «Стратегии социально-экономического развития Сибири и их реализация в XX - начале XXI в.».

\section{A. Ilyiniykh Institute of History Siberian Branch of RAS, Novosibirsk, Russian Federation

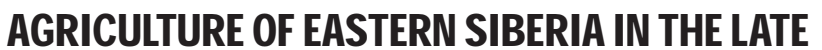 1980 — - 1990 \& DYNAMICS, SECTORAL, PRODUCTION

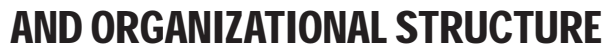

Abstract. The article reconstructs dynamics of agricultural development of Eastern Siberia in the 1990s, describes structural changes, and identifies key factors of the development of the industry. The author concludes that radical agrarian and economic reforms resulted in the most profound and sustained agricultural crisis in the region. The deepest crisis was in husbandry that was manifested in a sharp fall in the number of productive livestock. Sheep breeding suffered above all. Decrease in the number of livestock of all kinds occurred mainly at the expense of large farms. Crop areas reduction took place in plant growing. The most significant decrease was observed in sowing forage crops that was related to livestock reduction in the collective farms. At the same time, decrease of wheat crops in the region was insignificant as a whole. The Eastern Siberian agrarian sector of the economy experienced radical structural changes. Contrary to the plans of the reformers, the industry was dominated not by private farms and corporations, but by personal homesteads of rural residents. As a result, the inefficient state sector was replaced by the ineffective private sector. Tuva, Chita Oblast, Buryatia and Khakassia were the most heavily affected by the crisis regions because previously there the Soviet authorities promoted farming sys- 
tems that did not correspond to the local environmental conditions and mentality of aboriginal peoples.

Keywords. Agrarian reform of 1990s, agriculture, crop farming, livestock farming, Eastern Siberia.

Funding. The study was carried out as part of the project № 0326-2016-0001 «Strategies of socio-economic development of Siberia and their implementation in $20^{\text {th }}-$ early $21^{\text {th }}$ century».

Анализ развития сельского хозяйства и его отраслей относится к числу базовых задач аграрной историографии. Ее решение имеет принципиальное значение для определения результативности проводимых государством аграрных преобразований. В современных условиях одной из наиболее общественно значимых историографических проблем являются экономические последствия аграрной реформы начала 1990-х гг. Изучение темы в масштабах всей страны невозможно без реконструкции динамики сельхозпроизводства в отдельных регионах. В качестве объекта анализа в настоящей работе избрана Восточная Сибирь, куда в настоящее время входят Красноярский край, Иркутская область, Забайкальский край (до 2008 г. - Читинская область), республики Бурятия, Тыва и Хакасия.

Базовыми источниками изучения динамики аграрного производства региона служат материалы опубликованной сельскохозяйственной статистики, извлеченные из статистических сборников и ежегодников Госкомстата СССР и РСФСР, Госкомстата РФ (Росстата) ${ }^{1}$.

1 Развитие агропромышленного комплекса РСФСР : стат. сб. / Госкомстат РСФСР. М., 1989 ; Народное хозяйство РСФСР в 1990 году : стат. ежегодник / Госкомстат СССР. М., 1991 ; Сельское хозяйство в России : стат. сб. / Госкомстат России. М., 1998 ; Российский статистический ежегодник. 2000 / Госкомстат России. М., 2000 ; Сельскохозяйственная деятельность крестьянских (фермерских) хозяйств в России : стат. сб. / Госкомстат России. М., 2000 ; Сельское хозяйство в России: стат. сб. / Госкомстат России. М., 2002 ; Сельскохозяйственная деятельность хозяйств населения в России : стат. сб. / Госкомстат России. М., 2003 ; Сельское хозяйство, охота и лесоводство в России : стат. сб. / Росстат. М., 2009 ; Регионы России. Социально-экономические показатели : стат. сб. / Росстат. М., 2009. 
Основной специализацией аграрного сектора экономики Восточной Сибири в 1980-е гг. являлось животноводство, доля которого в общем объеме валовой продукции сельского хозяйства в 1986-1988 г. составляла 67 \%. Подотраслью животноводства, имеющей общесоюзное значение, являлось овцеводство. Среди экономических районов РСФСР Восточная Сибирь занимала третье место по поголовью овец и производству шерсти. Большая часть поголовья овец и коз находилась в Читинской области (40\% от общерегионального стада), Хакасской АО (17,3\%), Бурятской АССР (16 \%) и Тувинской АССР (14,2 \%). В Красноярском крае и Иркутской области ведущим направлением животноводства являлось молочно-мясное скотоводство. В Восточной Сибири также были представлены свиноводство и птицеводство, которые, как и молочно-мясное скотоводство, имели преимущественно внутрирегиональное значение. На обеспечение нужд региона также было ориентировано растениеводство. Большую часть засеянной пашни занимали зерновые культуры (в 1990 г. - 54 \%). При этом следует иметь в виду, что доля основной продовольственной культуры - пшеницы составляла лишь 43,5 \% зернового клина. На остальной его части (56,5 \%) размещались так называемые второстепенные хлеба, главным образом зернофуражные культуры. Если учесть, что 43 \% площадей засевалось кормовыми культурами, то можно сделать вывод, что производство продукции растениеводства в Восточной Сибири в первую очередь ориентировалось на обеспечение нужд животноводства. Доля технических культур, картофеля и овощей в общей посевной площади была минимальной и составляла 0,5, 2,1 и 0,3\% соответственно.

Абсолютно бо́льшая часть сельскохозяйственных угодий закреплялась за сельскохозяйственными предприятиями (колхозами, совхозами, подсобными хозяйствами). Удельный вес их посевов в общей посев- 
ной площади в 1990 г. составлял 98,4%. Фермерские хозяйства в конце 1980-х гг. были единичным явлением. 1,6 \% посевных площадей в Восточной Сибири приходилось на личный сектор аграрной экономики (приусадебные хозяйства, участки, отведенные для ведения коллективного огородничества и садоводства). Вклад хозяйств населения в производство зерновых, технических и кормовых культур был статистически ничтожным. В то же время они производили бо́льшую часть картофеля (76,3 \% от общерегионального валового сбора 1990 г.) и вносили существенный вклад в выращивание овощей (31,7 \%). Доля личных хозяйств в посадках картофеля составляла 64,9 \%, овощей - 25,2\%.

Основными производителями животноводческой продукции также являлись сельскохозяйственные предприятия. В них была сосредоточена бо́льшая часть поголовья продуктивного скота. Тем не менее ЛПХ продолжало играть значимую роль в снабжении населения региона продукцией животноводства, особенно мясом и молоком. В Восточной Сибири в 1990 г. на личных подворьях производилось 25,5 \% мяса, 30,2 \% молока, 8,8 \% яищ, 7,1 \% шерсти. Относительно высокие показатели удельного веса личного сектора аграрной экономики в производстве мяса имели Тувинская АССР (41,3 \%), Бурятская АССР (35,6 \%), молока - Тувинская АССР (52,2 \%), Читинская область $(46,8$ \%), Хакасская автономная область $(36,4$ \%). В целом удельный вес ЛПХ в общерегиональном производстве продукции сельского хозяйства в 1986-1988 гг. составлял 24,7 \%, продукции растениеводства - 20,6, животноводства $-26,8 \%$.

В 1986-1990 гг. наиболее динамично развивающейся отраслью сельского хозяйства Восточной Сибири являлось животноводство. Производство мяса в регионе в эти годы увеличилось по сравнению с предыдущим пятилетием на 18,2 \%, молока - на 17,1, яиц - на 2018. T. 19, № 1. C. 59-78 
18,9 \%. Исключение составляла шерсть, настриг которой снизился на 3,5 \%. Темпы развития растениеводства были ниже. Валовой сбор зерна вырос за пятилетие на 6,1%. Основными факторами наращивания сельхозпроизводства являлись ввод в эксплуатацию крупных птицефабрик и свинокомплексов, а также относительно благоприятные погодно-климатические условия. Темпы прироста валовой продукции сельского хозяйства в целом в годы двенадцатой пятилетки в регионе превосходили показатели трех предыдущих пятилеток [3, с. 169-170].

Сельское хозяйство Восточной Сибири являлось составной частью советской аграрной экономики, для которой была характерна высокая степень унификации. Организационно-производственной основой модели аграрного строя, функционирующей в 1960-1980-е гг., являлись крупные государственные сельскохозяйственные предприятия, в которые были превращены и колхозы. От совхозов они отличались лишь по формально-правовым признакам. Направленностью на унификацию отличалась политика регулирования отраслевой структуры сельского хозяйства. В Восточной Сибири это проявилось в насаждении земледелия в зонах, недостаточно пригодных для его ведения, и замене мясного отгонного скотоводства молочно-мясным с зимне-стойловым содержанием КРС.

Характерная для постсталинской модели аграрного строя СССР индустриализация сельского хозяйства, переход на оплату труда, не зависящую от конечных результатов, привели к нарастающему отчуждению работников сельхозпредприятий от земли и других средств производства и снижению эффективности сельского хозяйства. В этих условиях все более широкое привлечение финансовых и материальных средств в аграрный сектор экономики не сопровождалось устойчивым приростом производства. В конце 
1970-х - начале 1980-х гг. ситуация в сельском хозяйстве страны стала принимать кризисные формы. Резко упала эффективность производства, его фондоотдача, окупаемость применяемых средств, производительность труда, возросла себестоимость продукции. Снижение темпов прироста производства сельхозпродукции на фоне быстрого роста спроса на ценные продукты питания привело к возникновению напряженности в продовольственном снабжении населения. В связи с этим началась реанимация карточной системы [3, c. 174].

В Восточной Сибири изъяны, характерные для сельского хозяйства страны в целом, проявлялись еще более рельефно. В силу отдаленности и слабого развития транспортной инфраструктуры себестоимость производства была высокой, а рентабельность, соответственно, низкой. Более острый характер в Восточной Сибири имел дефицит трудовых ресурсов. Большинство сельхозпредприятий экономического района фактически были убыточными. Их функционирование обеспечивалось прямыми и косвенными дотациями, совокупные размеры которых превышали уровень большинства сельскохозяйственных регионов страны, включая Западную Сибирь. Следует также отметить, что Восточная Сибирь находится в зоне еще более рискованного земледелия, чем западная часть макрорегиона.

В середине 1980-х гг. с целью преодоления отчуждения тружеников села от средств производства в СССР началось массовое внедрение в сельское хозяйство мелкогрупповых форм организации труда с оплатой по конечному результату. Новые формы организации труда (коллективный и арендный подряды) стали одним из факторов улучшения ситуации в сельском хозяйстве страны. Однако качественных сдвигов в аграрном секторе экономики не произошло [2, с. 269-271]. Продовольственное снабжение населения продолжало 2018. T. 19, № 1. C. 59-78 
ухудшаться. Карточная система приобретала все более тотальный характер.

В начале 1990-х гг. к власти в России пришли сторонники радикальных реформ. По их мнению, гарантией решения аграрного вопроса в стране и создания эффективного сельского хозяйства могла стать лишь ликвидация советской совхозно-колхозной системы и создание новых субъектов хозяйствования на основе частной собственности на землю и имущество, превращение сельхозпроизводителя в собственника-предпринимателя, действующего в условиях нерегулируемой рыночной экономики [2, с. 96]. И хотя новые руководители страны удержались от реализации призывов к полной и одномоментной ликвидации «агрогулага» и всеобщей фермеризации, была осуществлена попытка достаточно радикальной аграрной реформы. В конце 1991 г. года были приняты соответствующие нормативные акты. В 1992 г. началась реорганизация колхозов и совхозов, которая предусматривала: передачу земли и средств производства в собственность трудовых коллективов сельхозпредприятий; раздел переданных фондов на индивидуальные паи; преобразование хозяйств в акционерные общества или иные разрешенные законодательством организационно-правовые формы [1, с. 229]. Преобразование сельхозпредприятий должно было создать экономическую и кадровую основу для массового создания так называемых крестьянских фермерских хозяйств (КФХ).

Изменения в аграрной сфере приобрели революционный характер. Сельское хозяйство реагировало на это как на всякую аграрную революцию - падением производства. В Восточной Сибири поголовье продуктивного скота в 2000 г. изменилось по сравнению с 1999 г. следующим образом: 


\begin{tabular}{|l|c|c|c|c|}
\hline & \multirow{2}{*}{ КРС } & Коровы & Свиньи & $\begin{array}{l}\text { Овцы и } \\
\text { козы }\end{array}$ \\
\cline { 2 - 5 } & \multicolumn{3}{|c|}{ на тыс. голов меньше } \\
\hline Восточная Сибирь & 1869 & 432 & 1230 & 6939 \\
\hline Республика Бурятия & 220 & 41 & 145 & 1167 \\
\hline Республика Тыва & 108 & 26 & 55 & 574 \\
\hline Республика Хакасия & 124 & 28 & 93 & 1333 \\
\hline Красноярский край & 642 & 177 & 443 & 617 \\
\hline Иркутская область & 417 & 87 & 287 & 251 \\
\hline Читинская область & 360 & 72 & 206 & 2996 \\
\hline & & & & \\
\hline Восточная Сибирь & 52,8 & 68,3 & 46,2 & 19,7 \\
\hline Республика Бурятия & 60,6 & 77,8 & 44,7 & 15,7 \\
\hline Республика Тыва & 47,3 & 64,9 & 15,5 & 53,2 \\
\hline Республика Хакасия & 51,9 & 69,2 & 35,4 & 10,7 \\
\hline Красноярский край & 50,7 & 62,5 & 52,4 & 16,8 \\
\hline Иркутская область & 50,1 & 69,8 & 50,8 & 23,9 \\
\hline Читинская область & 55,1 & 71,8 & 31,6 & 13,5 \\
\hline
\end{tabular}

В 1990-е гг. произошло резкое падение поголовья продуктивного скота. В наибольшей степени пострадало стадо мелкого рогатого скота. Численность овец и коз в Восточной Сибири сократилось в 5,1 раза. Достаточно интенсивным было снижение поголовья свиней (на 53,8 \%). Относительно более устойчивым оказалось молочное стадо. Коров в регионе стало меныше на 31,7 \%. Поголовье КРС снизилось в 1,9 раза. В Западной Сибири за 10 лет численность КРС сократилась на 50,1 \%, коров - на 37,7, свиней - на 35,3, овец и коз на $74 \%$.

В относительных величинах наиболее высокие показатели падения поголовья КРС были зафиксированы в Туве $(-52,7 \%)$, коров - в Красноярском крае $(-37,5 \%)$, свиней - в Туве $(-84,5 \%)$, Читинской области $(-68,4 \%)$, Хакасии $(-64,6 \%)$. Численность овец со- 
кратилась в Хакасии в 9,3 раза, Читинской области в 7,4, Бурятии - в 6,4 раза. В абсолютных величинах максимальным было снижение численности КРС, коров и свиней в Красноярском крае (на 642, 177 и 443 тыс. голов соответственно), овец - в Читинской области (на 2996 тыс. голов). Среднегодовое производство мяса, молока, шерсти и яиц в 1996-2000 гг. снизилось по сравнению с 1986-1990 г. в Восточной Сибири в 1,7, 1,5, 5,4 и 1,6 раза, в Западной Сибири - в 1,9, 1,6, 4,8 и 1,4 раза.

Посевные площади в Восточной Сибири в 2000 г. изменились по сравнению с 1999 г. следующим обра30M:

\begin{tabular}{|l|c|c|c|c|c|}
\hline & $\begin{array}{l}\text { Весь } \\
\text { посев }\end{array}$ & $\begin{array}{l}\text { 3ер- } \\
\text { новые } \\
\text { куль- } \\
\text { туры }\end{array}$ & $\begin{array}{l}\text { в том } \\
\text { числе } \\
\text { пше- } \\
\text { ница }\end{array}$ & $\begin{array}{l}\text { Кор- } \\
\text { мовые } \\
\text { куль- } \\
\text { туры }\end{array}$ & $\begin{array}{l}\text { Карто- } \\
\text { рель }\end{array}$ \\
\cline { 2 - 6 } & \multicolumn{5}{|c|}{ на тыс. га меньше/больше } \\
\hline Восточная Сибирь & -3703 & -1818 & -238 & -1910 & $+33,2$ \\
\hline Республика Бурятия & -412 & -104 & +19 & -308 & $-0,5$ \\
\hline Республика Тыва & -238 & -117 & -66 & -120 & $-0,6$ \\
\hline Республика Хакасия & -320 & -172 & -25 & -155 & $+6,6$ \\
\hline Красноярский край & -955 & -569 & -20 & -396 & $+18,2$ \\
\hline Иркутская область & -571 & -167 & +15 & -413 & $+9,7$ \\
\hline Читинская область & -1207 & -689 & -161 & -518 & $-0,2$ \\
\hline & & \multicolumn{5}{|c|}{$\%$} \\
\hline Восточная Сибирь & 51,5 & 55,9 & 86,7 & 41,9 & 120,0 \\
\hline Республика Бурятия & 46,4 & 70,9 & 112,4 & 20,8 & 97,2 \\
\hline Республика Тыва & 15,6 & 19,9 & 27,3 & 8,4 & 83,3 \\
\hline Республика Хакасия & 46,5 & 44,9 & 81,6 & 43,0 & 168,8 \\
\hline Красноярский край & 66,8 & 65,6 & 97,4 & 65,1 & 128,4 \\
\hline Иркутская область & 63,7 & 77,0 & 104,5 & 47,5 & 121,1 \\
\hline Читинская область & 21,8 & 26,1 & 49,1 & 9,8 & 99,1 \\
\hline
\end{tabular}


В Восточной Сибири пашни в 2000 г. засеяли почти наполовину меньше, чем в 1990 г. Наиболее значительно снизились (в 2,3 раза) посевы кормовых культур. Еще более резко сократились (в 3,1 раза) площади, занятые «второстепенными» зерновыми культурами. Рекордсменами в падении кормопроизводства в относительных величинах стали Тува, Читинская область и Бурятия, где посевные площади кормовых культур сократились соответственно в 12,10 , и 4,8 раза. В абсолютных величинах максимальным было сокращение посевных площадей в Читинской области (на 1207 тыс. га) и Красноярском крае (на 955 тыс. га). Посевы пшеницы в целом по региону уменьшились лишь на 13,3 \%. В Красноярском крае площади, занятые пшеницей, сократились минимально (на 2,6 \%), а в Бурятии и Иркутской области - увеличились на 12,4 и 14,5 \% соответственно. В итоге посевы зерновых культур в Восточной Сибири сократились на 44 \%. В то же время посадки картофеля в большинстве административно-территориальных единиц Восточной Сибири и в регионе в целом увеличились и лишь в Туве уменьшились. Минимальный прирост посадок картофеля был зафиксирован в Читинской области. В Западной Сибири за 10 лет посевные площади картофеля, зерновых и кормовых культур сократились на 3,2, 14,1 и 33,5 \%, а пшеницы увеличились на 2,9\%.

Существенные изменения произошли в структуре посевных площадей. Удельный вес кормовых культур в Восточной Сибири в целом сократился (с 43 до $35 \%$ ), а зерновых и картофеля - вырос (с 54 до 58,6 \% и с 2,1 до 5 \% соответственно). Наиболее значимыми стали сдвиги в структуре зерновых. Доля пшеницы в общей площади посевов и в посевах зерновых увеличилась в регионе с 23,4 до 39,5 и с 43,5 до 61,5 \%. Валовой сбор зерновых культур и пшеницы в 1995-2000 гг. в исследуемом регионе снизился по сравнению с 1986-1990 гг. на 45,7 и 30,8 \%. Картофеля собрали на 21,8 \% больше. 
В 1990-е гг. произошли значительные изменения в организационно-хозяйственной структуре сельского хозяйства страны и региона. Появился новый сектор аграрной экономики - фермерские хозяйства, официально именуемые крестьянскими (фермерскими) хозяйствами (КФХ). Несмотря на декларируемую государством поддержку фермерского движения, их доля в общей площади посевов в Восточной Сибири в 1999 г. достигла лишь 3,5%. Основной специализацией фермеров стало производство зерновых культур. В 1999 г. удельный вес посева КФХ в посевах зерновых культур составлял в регионе 4,9 \%. Вклад фермерских хозяйств в выращивание других культур был менее значимым. На их долю приходилось 1,5 \% посадок картофеля и $2 \%$ - овощей.

Сельхозпредприятия (OAO, ЗАО, ТОО, СПК, колхозы, совхозы, подсобные хозяйства предприятий и организаций), которые стали неофициально называться крупхозами, снизили удельный вес в производстве сельхозпродукции. Доля их посевов в общей посевной площади в Восточной Сибири сократилась с 98,4 до 90,5 \%. Наиболее существенно снизилось значение сельхозпредприятий в картофелеводстве. Их удельный вес в валовом сборе картофеля в регионе в 1990 г. составлял 35,1 \%, в 1999 г. - 3,3 \%. В посадках овощей доля крупхозов сократилась с 74,8 до 18,1 \%.

Личный сектор экономики не только компенсировал потери крупхозов в производстве картофеля, но и обеспечил его наращивание (см. выше). Посадки картофеля в хозяйствах населения выросли в 1999 г. по сравнению с 1990 г. в Восточной Сибири в 1,9 раза. Доля ЛПХ в валовом производстве картофеля в регионе в целом увеличилась с 76,3 до 96,4 \%, сборе овощей - с 31,7 до 83,9\%.

В личном секторе сельской экономики за 10 лет выросло поголовье КРС (на 6,6 \%) и коров (на 18,4 \%), а свиней и овец - снизилось (на 33,2 и $19 \%$ соответ- 
ственно). Однако темпы сокращения стада мелкого рогатого скота в ЛПХ были существенно ниже, чем в крупхозах. В результате доля поголовья овец и коз личных хозяйств в их общем поголовье выросла с 10,3 до 38,8 \% , свиней - с 41,2 до 65,6 \%, коров - с 35,5 до 59 \%, КРС - с 28,5 до 55,5 \%. В 1999 г. в хозяйствах населения региона производилось 67,8 \% мяса, 61,6 \% молока, 15,1 \% яиц. Удельный вес крупхозов в производстве мяса в Восточной Сибири в 1999 г. составлял 30,1%, молока $-36,6$, яиц - 84,7 \%. Вклад фермерских хозяйств в развитие животноводства в 1999 г. оставался незначительным. Их доля в производстве мяса составляла $2,1 \%$, молока 1,8, яиц - 0,2\%.

С 1991 по 1999 г. удельный вес крупхозов в общем производстве сельхозпродукции в регионе снизился с 67,6 до 29 \%. Доля фермерских хозяйств в валовом производстве составляла 1,8 \%. В хозяйствах населения в 1999 г. производилось 69,2 \% сельхозпродуктов (в стоимостном выражении). Максимальных значений по региону вклад ЛПХ в производство продукции достиг в Туве $(83,4$ \%), Читинской области $(81,5$ \%) и Бурятии $(78,3 \%)$. Относительно развитым было фермерское хозяйство в Туве (7,3 \% от общего объема сельхозпроизводства).

В сельском хозяйстве Восточной Сибири, как и всей страны в целом, в конще 1990-х гг. доминировали, вопреки предположениям идеологов аграрной реформы, не фермерские хозяйства, а личные приусадебные хозяйства сельских жителей. Фермерское движение переживало бум лишь в начале 1990-х гг., когда государство оказывало ему существенную поддержку. Однако к середине десятилетия интерес к фермерам со стороны государства резко снизился, поскольку они не смогли, как ожидалось, обеспечить быстрого подъема сельхозпроизводства. Условия для развития фермерских хозяйств стали ухудшаться. Правительство практически отказалось от выполнения федеральной програм2018. T. 19, № 1. C. 59-78 
мы поддержки фермерства. Все их проблемы были перенесены на региональный уровень. Прекратилось централизованное льготное кредитование, быстрыми темпами начали расти цены на материально-технические ресурсы. В этих условиях КФХ оказались в критическом положении - доход от реализации продукции не возмещал затрат на ее производство, в результате чего многие из них обанкротились [1, с. 269-270]. В итоге лишь незначительное меньшинство селян организовали фермерские хозяйства.

Крупхозы, напротив, продемонстрировали неожиданную для реформаторов живучесть. Абсолютное большинство бывших колхозников и работников совхозов не хотели выходить из хозяйств и получать паи, разделяя стремление «красных» директоров и председателей сохранить целостность сельхозпредприятий.

Динамика развития сельского хозяйства в 1990-е гг. определялась не только прямыми преобразовательными действиями, но и общей экономической политикой - «свободой цен», резким сокращением финансирования отрасли из бюджета. Практически не регулируемая государством рыночная стихия, усугубленная существованием крупных производственных монополий в сфере обслуживания сельского хозяйства (топливно-энергетический комплекс, сельхозмашиностроение, производство удобрений и гербицидов, переработка), привела к разоряющему все категории хозяйств диспаритету промышленных и сельскохозяйственных цен. Обвальное сокращение инвестиций из федерального и местных бюджетов особенно негативно сказалось на аграрном производстве высокодотационных регионов, к которым относилась и Восточная Сибирь.

Аграрный сектор не успевал приспособиться к быстро меняющимся условиям, ограничивающим его развитие. Многие хозяйства после проведенной реор- 
ганизации направляли свою деятельность скорее на самосохранение и выживание. Острая нехватка оборотных средств, нарастающие долги в бюджет, внебюджетные фонды, за потребленную энергию усиливали кризисное положение сельхозпредприятий. Лишь незначительная часть хозяйств смогла адаптироваться к рыночным условиям.

Наиболее глубоким был кризис в животноводстве. Кризисное состояние отрасли прежде всего проявилось в резком падении поголовья продуктивного скота. Уменьшение поголовья скота всех видов происходило преимущественно за счет крупхозов, которые не могли содержать животных в новых экономических условиях. В значительной степени это было обусловлено высоким уровнем затрат, спросовыми ограничениями населения ввиду неблагоприятного материального положения, неразвитостью системы сбыта продукции, падением объемов производства легкой промышленности. Поскольку хозяйства были не в состоянии поддерживать поголовье скота на прежнем уровне, они производили его массовый забой. При этом скот служил формой оплаты за долги хозяйств и выплаты зарплаты работникам. Сказались также и возросший падеж скота и недостаток молодняка для воспроизводства стада [3, с. 196].

Наиболее уязвимыми оказались крупные специализированные овцеводческие хозяйства. Отечественная текстильная промышленность, проигрывая конкуренцию дешевому китайскому импорту, значительно сократила производство продукции. Спрос на шерсть резко упал. В итоге в регионах, где были сосредоточены сельхозпредприятия, специализирующиеся на тонкорунном овцеводстве, произошло более чем восьмикратное сокращение поголовья.

В растениеводстве кризис проявился прежде всего в ежегодном сокращении посевных площадей. Наиболее значительно уменьшились посевы кормовых куль2018. T. 19, № 1. C. 59-78 
тур, что было связано с сокращением поголовья скота в крупхозах. По той же причине резко сократились площади, занятые зернофуражными культурами. В то же время снижение посевов пшеницы в целом по Восточной Сибири было относительно небольшим, а по ряду административно-территориальных единиц даже увеличилось. Приоритетное внимание сельхозпроизводителей к возделыванию пшеницы было обусловлено более высокими по сравнению с другими зерновыми культурами закупочными ценами, которые определяли относительно бо́льшую рентабельность ее выращивания.

Часть пашни выбывала из сельхозоборота в связи с отсутствием у крупхозов ресурсов для ее обработки. Низкая покупательная способность сельхозпроизводителей привела к упадку машиностроительного сектора, сферы инженерно-технических услуг. Производство основных видов техники для села уменьшилось в десятки раз. Количество техники, приобретенной всеми категориями хозяйств, резко сократилось. Устойчиво снижались не только количественные, но и качественные параметры машинно-тракторного парка. Резко повысилась степень износа техники. В 1990-е гг. была разрушена обслуживающая производство инфраструктурная сеть - ремонтная база, материально-техническое снабжение, агрохимическая и мелиоративная служба [3, с. 194].

Сокращение посевных площадей являлось основным фактором снижения валового производства зерна. На объемы зернового производства также влияло снижение урожайности хлебной нивы. В 1986-1990 г. в Восточной Сибири среднегодовой сбор зерна с одного гектара составлял 13,4 ц, в 1991-1995 гг. - 12, в 19962000 гг. - 11,2 ц. Погодно-климатические условия для выращивания зерновых в регионе в первой половине 1990-х гг. были менее благоприятными, чем в предыдущем пятилетии. Во второй половине 1990-х гг. усло- 
вия для возделывания хлебов ухудшились еще больше. Однако причины падения урожайности не сводились только к капризам сибирской погоды. В 1990-е гг. сельхозпроизводители были вынуждены отказаться от внедряемой в предыдущие годы интенсивной технологии выращивания зерновых культур 2 в силу ее дороговизны. Резко сократились масштабы применения минеральных и органических удобрений. Гербициды фактически перестали применяться. Посевы зерновых зарастали сорняками. Севообороты не соблюдались. Пшеница вновь, как в годы целинной кампании, становилась монокультурой. Удельный вес пшеницы в зерновом клине региона в 1990 г. составлял 43,5 \%, а в 2000 г. - 68,1 \%. В Хакасии и Туве удельный вес пшеницы в посевах зерновых достиг 79,3 и 86,2 \% соответственно. Плодородие почвы снижалось.

Таким образом, следствием радикальной аграрной и экономической реформы начала 1990-х гг. стал самый продолжительный и глубокий кризис сельского хозяйства Восточной Сибири. Особенно сильно кризисные явления проявились в животноводстве. В растениеводстве наиболее значительным было сокращение посевов кормовых культур, что связано с уменьшением поголовья скота в крупхозах. В аграрном секторе экономики региона в исследуемое десятилетие произошли радикальные структурные сдвиги. При этом, вопреки замыслам реформаторов, в аграрном производстве стали доминировать не фермерские хозяйства и акционированные предприятия, а личные

2 В 1980-е гг. под данным термином понималась совокупность приемов и методов ведения земледелия, обеспечивающих увеличение продуктивности пашни на основе комплексного применения средств химизации, мелиорации, комплексной механизации и внедрения передовых методов агротехники (размещение посевов по лучшим предшественникам, безотвальная вспашка и другие приемы защиты почвы от ветровой и водной эрозии). Интенсивная технология предполагала в первую очередь высокий уровень применения минеральных удобрений и ядохимикатов.

2018. T. 19, № 1. С. 59-78 
приусадебные хозяйства сельских жителей. В результате место неэффективного государственного сектора занял неэффективный частный. Расширение мелкотоварного производства обернулось снижением технологического и технического уровня ведения сельского хозяйства, что делало его архаичным и неконкурентоспособным.

Наиболее глубоким кризис сельского хозяйства был в Туве, Бурятии, Хакасии и Читинской области. В предыдущие годы аграрное производство в них отличались более высоким уровнем дотационности. Они были районами развитого овцеводства, а земледелие и молочно-мясное скотоводство с зимне-стойловым содержанием КРС искусственно насаждались в национальных автономиях региона в советский период и не корреспондировались с местными природно-климатическим условиям и менталитетом бывших кочевников, принудительно переведенных на оседлость.

$$
* * *
$$

Кризис сельского хозяйства Восточной Сибири, ставший следствием радикальной экономической и аграрной реформы начала 1990-х гг., продолжался и в первое пятилетие XXI в. В 2001-2005 гг. основной тенденцией в растениеводстве оставалось сокращение посевных площадей. Однако его темпы снизились. Менее интенсивным стал и сброс стада продуктивного скота. В то же время был зафиксирован рост в птицеводстве. В 2006-2010 гг. в аграрном секторе региона наметились точки роста. Увеличилось поголовье продуктивного скота и производство продукции животноводства. Наметившиеся во второе пятилетие XXI в. позитивные изменения были закреплены в последующие годы. Продолжалось поступательное движение в животноводстве. Начались восстановительные процессы в растениеводстве. За счет увеличения урожайности выросли валовые сборы зерновых культур. В начале XXI в. 
произошли изменения в организационно-производственной структуре аграрного сектора экономики. Существенно увеличился удельный вес КФХ в валовом производстве сельхозпродукции. КФХ и крупхозы потеснили личные хозяйства граждан.

Основным фактором, способствующим восстановительным процессам в сельском хозяйстве, являлась стабилизация социально-экономической ситуации в стране. Снизилась инфляция. Более доступными стали кредиты. Расширились масштабы государственной поддержки сельхозпроизводителей. Повысился платежеспособный спрос на сельхозпродукцию. Наращивались инвестиции в аграрный сектор экономики. Увеличившаяся доходность сельхозпредприятий позволила начать их техническое перевооружение. В растениеводство внедрялись интенсивные почвозащитные технологии. Увеличилась продуктивность скота и птицы. Однако в полной мере преодолеть последствия разразившегося в 1990-е гг. кризиса не удалось.

\section{Єписок использованной литературы}

1. Аграрные преобразования и сельское хозяйство Сибири в XX веке : очерки истории / В. А. Ильиных [и др.]. - Новосибирск : Сибпринт, 2008. - 308 с.

2. Проекты преобразования аграрного строя Сибири в XX в.: выбор путей и методов модернизации / В. А. Ильиных [и др.] ; ред. А. А. Николаев. - Новосибирск : Сибпринт, 2015. - 298 с.

3. Сельское хозяйство Сибири в XX веке: проблемы развития и кризисы / В. А. Ильиных [и др.]. - Новосибирск : Сибпринт, 2012. - 408 с.

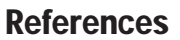

1. Ilinykh V. A., Andreenkov S. N., Rynkov V. M., Shilovskii M. V., Karpunina I. B. Agrarnye preobrazovaniya $i$ sel'skoe khozyaistvo Sibiri v XX veke : ocherki istorii [Agrarian transformations and agriculture of Siberia in the $20^{\text {th }}$ century: history essays]. Novosibirsk, Sibprint Publ., 2008. 308 p. 
2. Ilinykh V. A., Andreenkov S. N., Rynkov V. M. [et al.] ; Nikolaev A. A. (ed.) Proekty preobrazovaniya agrarnogo stroya Sibiri v XX v.: vybor putei i metodov modernizatsii [Projects of transformation of the agricultural system of Siberia in the $20^{\text {th }}$ century: the choice of ways and methods of the modernization]. Novosibirsk, Sibprint Publ., 2015. 298 p.

3. Ilinykh V. A., Nikolaev A. A., Rynkov V. M., Andreenkov S. N., Karpunina I. B., Melent'eva A. P. Sel'skoe khozyaistvo Sibiri v XX veke: problemy razvitiya i krizisy [Agriculture in Siberia in the $20^{\text {th }}$ century: problems of development and crises]. Novosibirsk, Sibprint Publ., 2012. 408 p.

\section{Инфрормация об авторе}

Ильиных Владимир Андреевич - доктор исторических наук, заведующий сектором аграрной истории Института истории Сибирского отделения РАН, 630090, Новосибирск, ул. Николаева, 8, e-mail: agro_iwa@mail.ru.

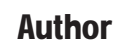

Vladimir A. Ilinykh - D.Sc. in History, Head of the Agrarian History Sector, Institute of History Siberian Branch of RAS, 8, Nicolaev str. Novosibirsk, 630090, Russian Federation, e-mail: agro_iwa@mail.ru.

\section{Для цитирования}

Ильиных В. А. Сельское хозяйство Восточной Сибири в конце 1980-х - 1990-е гг.: динамика, отраслевая и организационно-производственная структура / В. А. Ильиных // Историко-экономические исследования. - 2018. - Т. 19, № 1. - C. 59-78. - DOI: 10.17150/2308-2588.2018.19(1).59-78.

\section{4.}

Ilinykh V. A. Agriculture of Eastern Siberia in the Late 1980s - 1990s: Dynamics, Sectoral, Production and Organizational Structure. Istoriko-ekonomicheskie issledovaniya = Journal of Economic History \& History of Economics, 2018, vol. 19, no. 1, pp. 59-78. DOI: 10.17150/2308-2588.2018.19(1).59-78. (In Russian). 